\title{
Protection and Rational Use of Land Resources When Using Local Natural Fertilizers of Sapropel
}

\author{
Yurina N.A.* \\ Laboratory of Feeding and physiology of farm animals \\ Krasnodar Research Centre for Animal Husbandry and \\ Veterinary Medicine \\ Krasnodar, Russia \\ e-mail: naden8277@mail.ru
}

Machneva N.L.

Department of Biotechnology, Biochemistry and Biophysics,

Kuban State Agrarian University named after I.T. Trubilin,

Krasnodar, Russia

e-mail: 4806144@mail.ru

\begin{abstract}
The rational use of land has an important role in increasing the profitability of crop production in the Russian Federation, including the Republic of Adygea. The soil has indisputable functions that are significant for the country's food security. The main tasks of specialists in various fields of agriculture are the systematization and rational exploitation of lands assigned to a specific category, which should be aimed at rationalizing and preserving the fertile soil layer. The paper provides an analysis of the organization of the use and protection of land resources and describes measures to improve it in the Maykop region of the Republic of Adygea, including the use of Lake Sapropel as a fertilizer. It was found that the introduction of sapropel as a fertilizer contributes to an increase in triticale productivity by $12.9 \%$ and a decrease in soil acidity.
\end{abstract} acidity.

Keywords - land, soil, sapropel, triticale, productivity, soil

\section{INTRODUCTION}

The siltation of water bodies has become one of the most serious threats to aquatic ecosystems in the world, especially for water quality and can further negatively affect public health. With combined factors of climate change and human activities, eutrophication has expanded from shallow lakes in the temperature zone to water lakes in cold areas (called cold water lakes) $[1,2]$.

Eutrophication of water bodies is the main factor in their death. Moreover, even in the presence of canals, agricultural land is affected, especially in arid and semi-arid regions [3, 4].

Due to the natural eutrophication of water bodies, as well as anthropological activity, a large number of silt deposits appear; water bodies decompose and turn into swamps. There are many ways to reduce siltation of lakes and rivers - to carry out mechanical cleaning. However, at present there is a problem of disposal of sapropels and river sludges. Therefore, the use of bottom sediments for feed purposes is a very relevant topic [1, 2].

\author{
Yurin D.A. \\ Department of Livestock technology \\ Krasnodar Research Centre for Animal Husbandry and \\ Veterinary Medicine \\ Krasnodar, Russia \\ e-mail: 4806144@mail.ru \\ Tsipinova B.Sh. \\ Department of Land Management, Faculty of Agricultural \\ Technologies, \\ Maykop State Technological University \\ Maykop, Russia \\ e-mail: 4806144@mail.ru
}

Lake bottom sediments accumulate over the entire period of the reservoir. They are formed from the remains of organisms living in the lake and its environs. In fresh water, deposits are usually formed with a high organic content of substances (more than $15 \%$ ). Plants, plankton and bottom organisms for many years are transformed under the influence of bacteria and mixed with mineral components: sapropel is formed. It has a finely divided and colloidal structure, is a valuable resource and can be used in crop production, balneology, animal husbandry, the cosmetics industry, and other industries [5].

Recently, to increase soil fertility, increasing attention has been paid to finding effective ways to use different types of natural mineral raw materials. Based on sapropel, fertilizers can be produced and used for cultivated plants, both in solid and in liquid form. As a high-quality organic-mineral fertilizer, sapropel can be used for many types of soils and plants. Sapropels are classified as environmentally friendly and efficient agricultural product of natural origin. Therefore, one of the most promising areas is the use of bottom sediments for its processing and obtaining effective biostimulant products of plant growth. The best results are usually achieved when using liquid forms of sapropel fertilizers $[1,2]$.

Sapropel is an organic silt lake material created by the natural deposition of plant and animal substances for tens of thousands of years. It consists of a combination with fragments of higher plant tissue, pollen, sand, clay and various mineral solutions $[1,6,7]$.

In the upper layers, sapropel has the appearance of yellow jelly; in deeper layers it is slightly densified. Sapropel is rich in macro- and microelements, vitamins and biostimulants. In addition to a significant amount of carotene, the sediment of freshwater lakes contains vitamins D, B1, B2 and B12, folic acid and so on. It also contains calcium, phosphorus, sulfur and iron, as well as trace elements such as iodine, cobalt, copper, manganese, molybdenum, bromine, boron, zinc, 
nickel, titanium and others. Microorganisms secreting antibiotics were also found in sapropel; they inhibit the activity of pathogenic microbes. Sapropel is rich in proteins, carbohydrates, lipoids, and organic acids [1, 8].

It should be noted that sapropel varies in qualitative composition in different water bodies. Therefore, its chemical properties must be evaluated before use, and its effectiveness is confirmed by scientific research [1].

Sapropels are characterized by a high content of humic acids. The most common natural organic substances are humic substances containing up to $90 \%$ dissolved organic carbon in the aquatic environment and up to $70 \%$ organic carbon in the earth's environment. Humic substances form large pools of the organic component of soils, peat, composts and sapropel [9].

Humic compounds not only improve the absorption of trace elements by plants, but also enhance photosynthesis and root development. It is widely recognized that these substances are one of the most potential sources of humates used in agriculture [10-12].

Sapropels can indirectly and directly affect the physiological processes of plant growth. They improve mineral nutrition, increase the population of microorganisms, provide biologically active substances, and also contain plant growth regulators $[6,13]$.

Extraction of sapropel provides social and economic development for small and medium-sized businesses and improves the ecological quality of water bodies by reducing eutrophication caused by excessive accumulation of bottom sediments and soil erosion. In addition, sapropel extracting prevents siltation of lakes and their conversion into a swamp [14].

Fertilizer is a key step in achieving sustainable agricultural growth, development and productivity. The use of lake sapropels as fertilizers helps to increase the productivity of crops $[6,15]$.

In the Republic of Adygea there are many lakes and reservoirs, which are currently much silted and are in the process of eutrophication. Therefore, the use of sapropels as fertilizers includes not only benefits for the soil, but also for the reservoir itself, saving it from degradation.

The aim of the work is to analyze the organization of the use and protection of land resources and to develop measures for its improvement in the Maykop region of the Republic of Adygea, including the use of Lake Sapropel as a fertilizer.

Tasks:

- consider ways of protecting land resources in the Maikop district of the Republic of Adygea;

- to offer a complex of agro-reclamation, anti-erosion, recultivation, reclamation measures in the territory of Maykop district to improve the quality of land;

- study the composition of the sapropel of the Shapsug reservoir and determine its suitability for use in agriculture as a fertilizer;
- to study the effect of fertilizers based on sapropels on the productivity of winter triticale and soil condition.

\section{MATERIAL AND METHOD}

The object of the study is the land resources of the Maykop district of the Republic of Adygea, the problems of their rational use.

The subject of research is the sapropel of the Shapsug reservoir.

In the study of the effect of sapropel-based fertilizers on the agrochemical properties of the soil, the natural moisture sapropel of the Shapsug reservoir was used in experimental plots of meadow-and-chernozem soils $(3.2 \%$ of humus content) $2 \mathrm{~km}$ from Maykop. Experimental design: 1st plot (0.2 ha) - control, 2nd plot (0.2 ha) - experiment - application of sapropel in the amount of 10 tons per 1 ha. The studies were carried out according to the method of field experiment of B.A. Dospekhov (1985). The seeds of the Valentine-90 variety were planted on the plots. For sowing triticale were used aligned, sorted seeds with a purity of at least $98 \%$. Fertilization was carried out before sowing winter triticale in the autumn. Sowing rate: 6.5 million seeds per 1 ha. Seeding depth is $5 \mathrm{~cm}$.

The Shapsug reservoir is located in the left-bank floodplain of the Kuban River, is used for irrigation of agricultural land, mainly rice fields, and to protect settlements from floods, has a total capacity of 160 million cubic meters. It was founded in 1952 due to the earthen dam. By the nature of the water exchange it should be attributed to the accumulative-transit type. The flood control system is provided by regulating the spills of the Afips River.

Currently, the Shapsug reservoir is on the verge of death due to severe siltation. Therefore, it is necessary to find ways to utilize bottom sediments, including for fertilizing agricultural land.

\section{RESEARCH RESULTS}

Maykop district is part of the Republic of Adygea, is one of the seven municipal regions of the Republic. Maykop district is located in the southern part of the Republic of Adygea. Almost completely its borders (except for the northern part) coincide with the republican borders. In the north, the district borders on two municipalities of the Republic - the urban district, the city of Maykop and the Giaginsky district. Also, part of the northern border of the Maykop region separates its territory from the Belorechensky district of the Krasnodar Territory. In the east, the municipality "Maykopsky District" borders with Mostovskoy, in the west - with the Apsheron districts of the Krasnodar Territory. In the south it borders with the urban district of Sochi.

By the presence of the industrial and agricultural sector of the economy, the Maykop district of the Republic of Adygea belongs to the industrial and agricultural territories. The crops are mainly represented by cereals, such as wheat, barley, triticale, corn, as well as sunflower. In recent years, rape crops 
have been increasing. The system of agricultural production is clearly formed due to the available favorable resources: agroclimatic, weather. The analysis of the agricultural development of the region allows arguing about the increased potential for improving the territory: the actual set of resources contributes to the area successfully developing in the market aspect of modernity and increasing the growth of socioeconomic development of the region and the Republic of Adygea in particular.

Crop production is the main sector of the economy of the region. Successful development of agriculture in the territory should go along with the solution of important tasks:

- Strengthening the demand and marketing of agricultural products of the region in the market against the backdrop of import substitution policies;

- $\quad$ providing the population of the region with food in full;

- the development of high-quality, competitive and environmentally friendly products, the desire to produce organic agricultural products, this is especially true with the recreational importance of the Maykop region;

- Introduction of innovative methods of processing products in the district;

- the use of local, cheap and, most importantly, environmentally friendly raw materials for fertilizing agricultural land (sapropels).

In addition to the plant growing industry, the main structure of the agro-industrial complex of the region should be livestock farming, including alternative ones, such as ostrich, rabbit, and fish farming. The development of pond fish farming is very important for this territory, since the Republic of Adygea is rich in water bodies. But their death and eutrophication require clearing from sapropels. They are required to be used as fertilizers for plant growing. In addition, sapropels can also be used as feed additives for animal husbandry. In livestock breeding, the main tasks of increasing the economy of the industry are increasing the number and productivity of farm animals, optimizing breeding, improving the forage base, including the use of cheap fodder ingredients grown in environmentally friendly conditions of the Republic, as well as the use of local mineral and organic fertilizing sapropels. Cattle breeding, sheep breeding, horse breeding can become the main branches of livestock breeding in the region; it is also necessary to increase the number of poultry.

Land in the Maykop region is represented by the following categories: agricultural land, land of settlements, industry, transport and other special purposes, forest land, water fund land, specially protected natural territories and reserve lands. Agricultural lands include arable land, perennial plantations, meadows, hayfields and pastures. An analysis of the distribution of land in the region by category over the past 3 years shows that the largest part of the land is agricultural land, which area is 43921 hectares. The forest fund represents $58 \%$ of the total land.
Under arable land in Maykop district of the Republic of Adygea, $87 \%$ of the total agricultural land is allocated. The area of arable land with the highest soil score (86-87) is $46.0 \%$. The remaining areas of arable land $(54.0 \%)$ have a score of $72-78$.

The main reason for the loss of arable land is the lack of financial and technical capabilities and rural producers to maintain them in good condition.

A plan of measures to reduce the impact of negative exogenous geological processes that adversely affect the soil condition of agricultural land in the territory of the Maykop district of the Republic of Adygea has been proposed and is being actively implemented as follows

1. Ensuring the elimination of leaks in sewer networks, minimizing the operation of canalized sewers;

\section{Improvement of reclamation systems;}

3. Minimization of the rise of groundwater, timely monitoring and construction of drainage canals and other structures, drainage systems.

The system of measures to protect the air basin is focused on reducing harmful emissions and the atmosphere with an increase in the number of industrial and agricultural industries, as well as the intensity of their technological processes in the Maykop district:

1. Enterprises should minimize emissions by applying lil transition to more environmentally friendly technologies;

2. Priority in the allocation of land for construction to enterprises in whose business plan includes environmental production;

3. The use by enterprises of environmentally friendly alternative fuel in the operation of equipment;

4. Mandatory availability of sanitary zones at enterprises and green spaces

Activities in the agricultural sector are aimed at reducing negative processes that reduce soil fertility and worsen their quality.

1. Work on the definition of depleted and degraded lands.

2. Reducing the economic burden in the territories of depleted and degraded lands.

3. Carrying out agricultural, phyto-reclamation and antierosion measures aimed at improving agricultural land, increasing the content of humus and nutrients in soils, and protecting soils from deflation and salinization.

\section{Development of specially protected natural territories.}

The evolution of natural complexes based on fundamental approaches: basin (catchment), ecosystem, biogeochemical, population-biological, hydrogeological and hydrochemical. It is the studies of the state and evolution of representative ecosystems of catchments of a certain rank that make it possible to understand the laws of the structure and functioning of both specific forest biogeocenoses and the ecosystem of the entire catchment as a whole. 
The conservation of soils and their fertility is one of the most important tasks of land conservation. Soil is an indispensable and unique natural object covering the surface of the earth. Agricultural production should be carried out in ways that ensure the reproduction of the fertility of agricultural land, as well as excluding or limiting the adverse impact of such activities on the environment. Measures should be taken to protect land from water and wind erosion, waterlogging, compaction, contamination with radioactive and chemical substances, littering with industrial and household waste, and other processes leading to land degradation.

One of the most important means of increasing land fertility and soil conservation is land reclamation, which is carried out in order to increase productivity and sustainability of agriculture, to ensure guaranteed production of agricultural products based on the conservation and increase of land fertility, and to create the necessary conditions for involving unused and unproductive land and the formation of a rational structure of land.

Agrotechnical measures that limit the development of plant diseases by rust consist in an improved content of grain crops. The chemical method of control is economically beneficial only for the destruction of rust on perennial crops held in the district. Agrotechnical measures consist of the use of soilprotective properties of the plants themselves - perennial grasses and annual crops, anti-erosion tillage techniques, special methods of snow retention and regulation of snowmelt; agrochemical means to increase the fertility of eroded soils. Agrotechnical measures are of paramount importance in an integrated system of plant protection against pests, diseases and weeds. Most agricultural activities are preventive in nature, preventing or limiting plant damage by pests and diseases. With the help of some agricultural methods, it is possible to directly destroy pests.

Agricultural activities play an important role in weed control. In all farms, measures are taken to mow the weeds around the site, periodically carefully weed them by hand, tearing along with the roots and preventing seeding. During the spring and autumn digging, the soil is cleaned of weed rhizomes, which are dried and burned. Agrotechnical measures are carried out in order to prevent wind and water erosion and increase soil fertility. These include horizontal tillage, deepening of the cultivated arable layer, snow retention, regulation of snow accumulation, fertilizing, stock control and water retention techniques, etc. In areas where wind erosion predominates, a subsurface tillage system with the introduction of mineral fertilizers is carried out, as well as stubble, so tall stalked grasses. These techniques reduce wind speed and accumulate snow in the fields.

Agrotechnical measures require compliance with the proper conduct of agricultural work. So, in areas subject to erosion, plowing is carried out across the slopes, followed by the cultivation of plants with a sufficiently developed root system. In the coastal water protection zone, the slopes should be withdrawn from agricultural use and tinned. Grazing on steep slopes is prohibited. Agricultural activities mainly include measures to prevent soil erosion. This is, first of all, tillage and sowing of agricultural plants across the slope.
Additional measures include the creation of water-holding furrows and rollers, hole formation, slotting, snow retention and protection of the soil from freezing. Agrotechnical measures to increase the irrigation rate can be divided into two groups. Of the hydraulic measures on irrigated lands, shaftsterraces with a wide base and step terraces are used. The influence of agricultural activities on precipitation is mainly manifested in the effect on the snow cover. In this work, other data on snow reserves on various sites are presented. It can be concluded that the presence of vegetation or dead vegetation in the fields in winter contributes to a greater accumulation of snow compared to the autumn plowing. An increase in snow reserves in the fields is also created by snow retention. Moreover, depending on the natural zone and winter conditions, the water reserves in the snow in the fields may increase. In the system of agrotechnical measures to combat weeds: vegetation, a special place belongs to chaffinch tillage, the first method of which is peeling. The depth of peeling, the timing of its implementation, the processing tools are selected depending on the soil conditions, the degree of contamination of the species composition of weeds. In the system of agricultural measures to combat drought, the methods of accumulating moisture in the soil and its rational use are important. Subject to agrotechnical measures, the weed is easily suppressed and destroyed. A simple and affordable agro-technical measure to combat water erosion is soil treatment across the slope. It creates a peculiar microrelief of arable land, as a result of which ridges, grooves, rows of crops interfere with surface runoff, facilitate the penetration of water into the soil and increase its reserves in the arable horizon, and prevent flushing.

From the arsenal of past agricultural activities, only those that guarantee us high labor productivity in agricultural production and a real fight against drought, the struggle for the crop should remain. The steam farming system and related individual agricultural measures should be replaced by the grassland farming system as a socialist system of continuous collectivization of agriculture, which can only be used in organizations and farms. A rational crop rotation, being one of the largest events in the struggle for quality, the struggle for the organizational and economic strengthening of collective farms and the qualitative improvement of the work of state farms, must ensure the following basic requirements,

Agrotechnical measures that improve soil quality consist in an improved content of grain crops using the soil-protective properties of the plants themselves - perennial grasses and annual crops, mainly legumes, methods of anti-erosion treatment of soils, special methods of snow retention and regulation of snowmelt, agrochemical means to improve the fertility of eroded soils, application biofertilizers, organic, natural mineral fertilizers, including sapropels.

Measures to improve the condition of agricultural land in the Maykop district of the Republic of Adygea are aimed at eliminating the negative consequences that worsen soil fertility and their quality.

1. Implementation of measures to determine and organize the improvement of depleted and degraded lands; 
2. Reduction of industrial and agricultural load on depleted and degraded lands;

3. Carrying out agrotechnical, phyto-reclamation and antierosion measures aimed at improving agricultural lands, increasing the content of humus and nutrients in soils by applying organic fertilizers, sapropels, and protecting soils from salinization.

Starting with elementary catchments, as information accumulates, testing methods and research techniques are developed, include in the monitoring system more and more large catchments, up to the rivers flowing into the Krasnodar reservoir (for example, the Belaya river basin).

Optimization of the ecological balance in this basin plays an important role in the livelihoods of Adygea, in particular, in resolving issues of water supply, food and a health-improving base, as well as various types of recreation in the south of Russia.

Including an important component of maintaining the ecological balance is the cleaning of lakes and reservoirs from silt sediments.

Sapropel samples of the Shapsug reservoir of the Republic of Adygea were selected for laboratory research.

Sapropel for analysis was taken by the bottom scoops from control points by the envelope method, combining them into a laboratory sample. Bottom sediments were taken from a depth of $1.0-1.2 \mathrm{~m}$ from the surface.

In the course of the studies, the following were determined: the mass fraction of moisture in the samples, total nitrogen, crude fiber, raw ash, calcium, phosphorus, sodium, magnesium, potassium, iron, zinc, manganese, copper, cobalt, lead, arsenic, cadmium, mercury according to generally accepted test procedures.

According to GOST R 54000-2010, sapropel class 1 suitability for use in agricultural production as fertilizers should contain: (no more than $\mathrm{mg} / \mathrm{kg}$ ): cadmium 3, zinc 300 , lead -50 , copper -100 , mercury $-1,0$, manganese -500 , cobalt -20 . In the samples presented, these indicators did not exceed the maximum permissible levels. Consequently, the sapropel of the Shapsug reservoir belongs to the bottom sediments of the first class of suitability in agricultural production.

The content of total carbon, humic and fulvic acids was determined in the sapropel samples by extraction in a $0.1 \mathrm{~N}$ $\mathrm{NaOH}$ solution. The total carbon in the studied samples was found in the amount of $4.8 \mathrm{~g} / 1$. Humic acids in the sapropel of the Shapsug reservoir were found $2.0 \%$, and fulvic -2.8 $\%$.

According to physico-chemical parameters, these bottom sediments can be attributed to organo-calcareous. The particle content in samples of more than $10 \mathrm{~mm}$ did not exceed $18.0 \%$, the content of ballast mechanical inclusions did not exceed $0.9 \%$, the $\mathrm{pH}$ of the salt extract in the first sample was 6.2 , in the second sample -6.4 .
Pathogenic microflora, including E. coli, enterococci, staphylococci, clostridia, as well as viable eggs and helminth larvae, were not found in the samples of bottom sediments of the Shapsug reservoir.

When determining safety indicators in sapropel, it was found that $\mathrm{HCH}$ (alpha, beta, gamma isomers), 2,4-D acid, its salts and esters, DDT and its metabolites were not detected.

Therefore, this sapropel is quite suitable in its chemical composition for use in agriculture as a fertilizer.

In the course of the research on the effect of sapropel as a fertilizer on the triticale yield, the high yield of the latter was established, due to favorable climatic conditions in this period. Weather conditions during the growing season of the studied culture in 2019 were favorable. In May, intermittent rains were observed with daytime air temperature from +16 to $+30{ }^{\circ} \mathrm{C}$. In early June, temperatures were high and fluctuated during the day from +28 to $+32{ }^{\circ} \mathrm{C}$, with short-term but heavy rains. From mid-June, drier weather with rare rains and lower temperatures recovered, which favorably affected the formation of triticale grains.

In the course of the study on the effect of applying sapropel as fertilizer, the humus content in the soil in the control plot corresponded to $3.4 \pm 0.2 \%$, while in the experimental plot $-5.4 \pm 0.3 \%(\mathrm{P}<0.001)$. The $\mathrm{pH}$ of the soil in the control was $5.55 \pm 0.5$, and in the control $-5.77 \pm 0.6$. The yield of triticale in the control was 8.5 tons per hectare, and in the experiment -9.6 tons per hectare, which is $12.9 \%$ higher.

\section{CONCLUSION}

The measures to protect lands from pollution and contamination are established with the aim of eliminating or limiting the influence of anthropogenic and natural factors causing these phenomena, and to restore the lost fertility level and the quality of contaminated and infected lands. At the same time, it is important to develop methods for improving the condition of land. The sapropel of the Shapsug reservoir belongs to the 1 st class of suitability in agricultural production. It was found that the introduction of sapropel as a fertilizer contributes to an increase in triticale productivity by $12.9 \%$ and a decrease in soil acidity.

\section{References}

[1] N.D. Labutina, D.V. Osepchuk, D.A. Yurin, N.A. Yurina, B.V. Khorin D.D. Kulova, "Comparative Analysis of The Chemical Composition of Bottom Sediments of Freshwater Basins of The Krasnodar Territory for Use as A Raw Material for Agricultural Production”, Amazonia Investiga, vol. 8, no. 20, pp. 668-673, 2019.

[2] N.A. Yurina, S.I. Kononenko, A.B. Vlasov, A.A. Danilova, A.N. Gneush, "Natural Feed Additive in Rations of Laying Hens", J. of Pharmac. Sci. and Res., vol. 10, no. 7, pp. 1860-1862, 2018.

[3] M.E.A. El-sayed, G.M.M. Soliman, A.F. Ahmed, "Impact of Silicon an Humic Acid Application under Water Stress Condition on some Bread Wheat Cultivars and Some Soil Properties", Assiut J. Agricult. Sci., vol. 49, no. 4, pp. 138-157, 2018.

[4] E.E. Bakšien, M.A. Fullen, C.A. Booth, "Agricultural soil properties and crop production on Lithuanian sandy and loamy Cambisols after the application of calcareous sapropel fertilizer", Archives in Agron. and Soil Sci., no. 52, pp. 201-206, 2006 
[5] K. Stankevica, Z. Vincevica-Gaile, M. Klavins, "Role of humic substances in agriculture and variability of their content in freshwater lake sapropel", Agron. Res., No 17(3), pp. 850-861, 2019. Retrieved from: https://doi.org/10.15159/AR.19.094

[6] S.A. Shahid, A.A. Qidwai, F. Anwar, I. Ullah, U. Rashid, "Effects of a Novel Poly (AA-co-AAm)/AlZnFe2O4/potassium Humate Superabsorbent Hydrogel Nanocomposite on Water Retention of Sandy Loam Soil and Wheat Seedling Growth Molecules", Nov 2012, vol. 17, no. 11 , pp. 12587-12602. DOI: 10.3390/molecules 171112587

[7] K. Maghsoudi, Y. Emam, M. Ashraf, "Foliar application of silicon at different growth stages alters growth and yield of selected wheat cultivars", J. of Plant Nutr., vol. 39, no. 8, pp. 1194-1203, 2016.

[8] F.M. Thalooth, A.T Manal, G. Amal, H. Ahmed, Mohamed Magda, T.A. Elewa, "Evaluation of the effect of chemical fertilizer and humic Acid on yield and yield components of wheat plants (Triticum aestivum L.) grown under newly reclaimed sandy soil", Int. J. of Chem. Tech. Res., vol. 9, no. 8, pp. 154-161, 2016.

[9] K. Stankevica, M. Klavins, L. Rutina, A. Cerina, "Lake Sapropel: a Valuable Resource and Indicator of Lake Development", Advances in Environment, Computational Chemistry and Bioscienc, pp. 247-252, 2012.

[10] C. Spagnol, F.H.A. Rodrigues, A.G.V.C. Neto, A.G.B. Pereira, A.R. Fajardo, E.A.F. Rubira, E.C. Muniz, "Nano composites based on poly(acrylamide-co-acrylate) and cellulose nanowhiskers", Eur. Polym. J., no 48, pp. 454-463, 2012. DOI: 10.1016/j.eurpolymj.2011.12.005

[11] N.A. Golubkina, S.P. Zamana, M.M. Tareeva, V.Yu. Mukhortov, V.F. Pivovarov, "Comparative evaluation of the influence of humates and bacterial fertilizer of biostar on the accumulation of selenium, zinc and copper by plants using organic fertilizers", Agricult. Biol., vol. 45, no. 3 , pp. $41-45,2010$.

[12] A.A. Kandil, A.E.M. Sharief, S.E. Seadh, D.S.K Altai, "Role of humic acid and amino acids in limiting loss of nitrogen fertilizer and increasing roductivity of some wheat cultivars grown under newly reclaimed sandy soil”, Int. J. Adv. Res. Biol. Sci., vol. 3, no. 4, pp. 123-136, 2016.

[13] A.S.A. Amjad, Y.M.A. Khanif, H.A. Aminuddin, O.A. Radziah, H.A. Osumanu, "Impact of potassium humate on selected chemical properties of an Acidic soil", 1-6 August 2010 [Proc. of 19th World Congr. of Soil Sci., Soil Solutions for a Changing World]. Brisbane, Australia.

[14] C.A. Booth, E. Baksiene, M.A. Fullen, A. Ciunys, A. Booth et al., "Long-term agrochemical dynamics: engineering, application and challenges ofcalcareous sapropel as a soil fertilizer", Int. J. of Ecodynam., vol. 2, no. 2, pp. 108-116, 2007.

[15] E. Karpukhina, I. Mikheev, I. Perminova, D. Volkov, M. Proskurnin "Rapid quantification of humic components in concentrated humate fertilizer solutions by ftir spectroscopy", J. of Soils and Sediments, vol. 19, no 6, pp. 2729-2739, 2019. 